\title{
Shichao Chang,
}

Zhejiang Golden Egg technology LTD, China,

Taras Shevchenko National University of Kyiv, Ukraine

(iD) ORCID ID: 0000-0003-2945-52206

\section{IMPLEMENTATION OF INNOVATION IN THE COMPANY: SITUATION ANALYSIS}

Abstract. The article is devoted to introducing innovations in the company - one of the most important ways of transforming the production process in the company's activities. The purpose of the article is to substantiate scientific and practical provisions for a comprehensive assessment of the effectiveness of introducing innovations and developing recommendations for increasing the innovative potential of a company, based on the use of a situational analysis of dynamic indicators of innovative changes. Literature processing shows that not enough attention is paid to problematic aspects of situational analysis and methods of assessing domestic companies' implementation to build up their innovative potential. The article's relevance lies in need to use the economic and mathematical apparatus of calculation to justify the feasibility of introducing innovations in a company to strengthen competitive positions in the market. Methods for assessing the implementation of innovations in a company are analyzed based on the classification properties. Methods for assessing the implementation of innovations for their application in the company's innovative development are analyzed. The existing methods for assessing the effectiveness of the company's innovative activities are systematized. Methods of situational analysis are considered in the example of energy saving. Typical scenarios for the implementation of the efficiency of energy-saving measures in the company are presented. The calculation of the innovation project's absolute effect was carried out (the profit from the introduction of new equipment and the growth of profit from the replacement of existing equipment were determined). The calculation of the efficiency of replacing existing equipment (basic version) with new equipment for an innovative project (new version) has been performed. The organizational and economic support of the assessment of innovative activities in the company is investigated. Methodological approaches have been developed for the previous and final situational analysis of innovative projects and the company's innovative potential as a whole. The characteristics of the objective prerequisites for the growth of the company's innovative potential are given. Based on a review of the state of the company's innovative activities, a system of analytical indicators for assessing the feasibility of a project or choosing the best project is proposed. The study's applied significance lies in the fact that the proposed assessment methods and tools, when applied in practice, make it possible to intensify companies' innovative activities and increase their competitiveness in the market.

Keywords: efficiency, measures, innovation, innovative project, assessment methods, situational analysis.

Introduction. A feature of the development of the national economy is constructing an economy to generate, disseminate, and use knowledge. The unique abilities of specialists, the ability to adapt them to changing activity conditions, and high qualifications are becoming the leading innovative resource for the company's sustainability of development and social value. One of the main signs of the weakness of the competitive advantages of the innovation environment of Ukrainian companies is their low innovation potential. At the same time, the investment efforts that business spends on innovations are observed in the context of an imbalance in economic development, ineffective mechanisms for the transfer of new knowledge in domestic and international markets. The question arises about choosing methods for assessing the effectiveness of introducing innovations into a company, developing ways to increase its innovative potential based on a situational analysis of innovative changes' dynamic indicators.

Literature Review. The scientific interest in assessing the implementation of innovations in companies made it necessary to analyze the accumulated array of theoretical and analytical materials on this issue. Thus, many foreign scientists (Varis and Littunen, 2010; Helfat and Quinn, 2006) study innovation's content aspects. Theoretical approaches to the relevance of introducing innovations for building the

Cite as: Chang, S. (2020). Implementation of Innovation in the Company: Situation Analysis. Marketing and Management of Innovations, 4, 290-303. http://doi.org/10.21272/mmi.2020.4-24 
company's potential and assessing innovations' effectiveness make us turn to the analysis of the accumulated theoretical material. Problems, forecasts, and innovation at enterprises are reflected in the works (Amara and Landry, 2005; Antikainen et al., 2010; Boons et al., 2013). The works are devoted to the applied aspects of assessing the effectiveness of the use of innovative potential (Dachs et al., 2008; Dewar and Dutton, 1986; Forsman, 2011; Fosfuri and Tribo, 2008). The works (Brem et al., 2016; Cho and Lee, 2015; Evangelista et al., 1997) show the practical foundations of innovative management. Jaffe (1986), Murovec and Prodan (2009) made a significant contribution to developing innovative development theory. Investments in intellectual (human) capital determine the most efficient way to allocate and reduce resources' innovative capacity (Maskell, 2000; Fountain, 1998). At the same time, in the economic literature, the problems of analysis and assessment of the introduction of innovations in companies are considered at a fragmentary level (Archibugi, 1996; Basant and Fikkert, 1996). Basically, only certain aspects of increasing individual companies' innovative level are studied (Belderbos et al., 2004; Cappa et al., 2016). All this does not allow identifying system-wide economic patterns and developing a unified model to increase the company's innovative potential. The article's topic resulted from the insufficient attention to methods of assessing the effectiveness of the introduction of innovations to build up the innovative potential of a company using situational analysis. The most common method for evaluating the effectiveness of investment (innovative) projects, based on discounting methods. NPV (net present value or project profitability) is often used. A project is considered eligible if its net present value (NPV) is positive. Although, if it is negative, the project must be rejected. The essence of discounting is to bring income and expenses of deferred periods to the project's year. The discounting technique is considered in such scientists' works: Jones (1995), Loof and Heshmati (2006). Some authors point out some disadvantages of the discounting method. So, from the point of view of researchers, «such estimates can be arbitrary, which distorts the real financial viability of the project ... and partly explains why in practice the criterion of the payback period of the project is so actively used, oriented towards the short-term horizon» (Pisano and Gary, 1990). Other scholars note that the NPV method in some cases «is not an absolutely correct criterion ... the use of the method is complicated by the difficulty of predicting the discount rate» (Remer and Nieto, 1995). Particularly harsh and reasoned against the generally accepted standard methods for evaluating innovations based on discounting principles are Newman, Gao, Zheng. In their opinion, these methods do not correspond to the economy of the XXI century, its high rates of recovery of products, equipment and new conditions of competition. They disorient investors; most of the investments are invested in non-productive sectors and risky operations in the securities markets (Newman et al., 2015).

Results. Today it is difficult to imagine an economy without constant improvements and innovations: companies do not stand still, strive to grow constantly, stand out from competitors, and regularly introduce goods, services and technologies to the market of varying degrees of novelty. Working with innovations differs from other self-improvement methods by using fundamentally new solutions that have not been previously used in the company. Thanks to the implementation of innovations, it is possible to: solve problems with the product range (launch a new product or improve an existing one); optimize production costs due to the use of innovative materials and/or technologies, production automation systems; improve the production and sales management system by introducing a new information product, software, personnel management methods, and the latest marketing solutions. Before implementing any innovations, analysis and preparation should be carried out, that is, adequately assess the company's need for innovations, draw up an algorithm for work, and plan the result. The first question that every manager should ask himself is what kind of innovations are needed in the company, and are they needed at all? (Milgrom and Roberts, 1995). When deciding on the introduction of innovations in a particular company, it is inappropriate to be guided exclusively by fashionable stereotypes of the market and the principle «all successful businessmen do this». It should be borne in mind that innovation is a means to make a company's work more productive, not an end in itself.Any innovation comes with a cost, so it is 
important to be clear about the future benefits of these costs and whether they will pay off at all. For determining the set of necessary innovative transformations, it is useful to conduct a preliminary analysis of the company's activities, financial indicators, and demand dynamics. The analysis should result in a clear understanding of the company's weaknesses; innovations should neutralize weaknesses; thanks to innovations, the company must achieve a specific result; time frame for achieving this result (Grimaldi et al., 2012). Suppose the object of the introduced innovation is the final product, not improving the production method. In that case, it is necessary to analyze whether this novelty is ripe for the market carefully.

The manufacturer must remember that a new product must be beneficial not only to himself but also to the consumer for a successful implementation. Therefore, the benefit from replacing the old product with a new one must cover the material and psychological costs of purchasing and adapting to the product (Griliches, 1979).In the first case, it will be advisable to create its own research unit or reorganize one of the existing services, for example, the service of the chief technologist or the design department. This approach makes it possible to avoid high one-time costs since the investment costs are spread over time. However, there is a risk that long-term work on developing an innovation will not bring the expected results. To buy an innovation, a company may establish a strategic partnership with a specialized research or development organization (Karim, 2009). This option is beneficial because the company receives a readymade innovation developed by specialists without time-consuming internal services and the risk of failure. Still, it will require high one-time financial costs. For investments to be effective, before choosing a partner, thorough research of the market for new technologies and a detailed analysis of the base of institutions specializing in innovative technologies are required (Amara and Landry, 2005; Prokop et al., 2017). There is also the option of joining with another company to develop an innovation jointly. This method allows for combining experience and share costs and risks. In turn, it also has its drawbacks as follows: in the long term, the interests of partner companies may change, and it becomes difficult to manage the process; difficult to dispute, difficulties with the allocation of intellectual property rights may arise (Antikainen et al., 2010). The introduction of innovations from the point of view of personnel and resource management can be carried out by the following methods: a) the coercive method is based on the use of force to overcome resistance from the side of personnel. It is advisable to apply it in the case when the nature of resistance is transparent, and innovations must be implemented in a short time; b) the method of adaptive deviations, on the contrary, involves the gradual introduction of changes over a long period by a specially created project group, and not by the head of the company, conflicts are resolved through a compromise.

Methodology and research methods. The method is favourable because the staff does not have to be «broken» (which can negatively affect the work's quality). Thus, the employees themselves subsequently accept the convenience and benefits of innovations. This method is used in cases where there is no urgency, and changes in the external environment are easy to predict; in emergencies, it is ineffective; c) crisis management is applicable to the most unfavourable cases when the company's existence is threatened. In this case, resistance is low, but there is a severe lack of time and the risk of failure; d) resistance management method - a flexible method that involves a combination of approaches of the method of adaptive deviations and forced, manoeuvring between them when the necessary urgency of implementation changes (Maskell, 2000). When introducing any innovation process, the leader must be prepared because the innovation will inevitably face difficulties, the main one of which is resistance from employees. The staff does not always accept innovations with enthusiasm, since innovations carry an element of discomfort: they require abandoning the usual, worked out methods of work, adapting to new, unknown conditions, additional training (Belderbos et al., 2004). Often, lower-level managers consider innovation a threat to their status, feel uncertain about the future, and anticipate increased control. In such cases, for the successful implementation of changes, it is advisable to take the following steps: to analyze the field of forces, that is, to identify the driving (promote innovation) and restraining (oppose innovation) forces, take into account their power. For innovation success, driving forces must prevail, so it is important 
to identify potential driving forces and set them in motion (Cassiman and Veugelers, 2006). The leader/manager's task is to convince the performers of the expediency and usefulness of transformations. It is important to identify the root causes of resistance in the team for working with potential forces. The most common reasons are the following: a) misunderstanding of the situation (associated with a low level of trust in management and misinterpretation of its intentions); b) differences in the assessment of the situation (occur in cases when employees have important information, in their opinion, unknown to management - it is important to identify this information); c) fears associated with the innovation loss of income, status; d) low tolerance for changes (based on natural conservatism or fear that as a result of innovation there would be a lack of knowledge, skills) (Grimaldi et al., 2012). Choose methods for overcoming resistance that is suitable for the reasons: a) high-quality informing of employees about the goals and processes of introducing innovations, including conducting confidential conversations; b) involving employees in the process (for example, providing the opportunity to develop individual details); c) organization of assistance and support in the development of innovations. Coercion under the threat of losing a position, job promotion - takes place, but is undesirable in the long term, the method, since it does not resolve the conflict (Fosfuri and Tribo, 2008). To improve the general preparedness of personnel for the innovation process, it is useful not only during implementation, but also in the current mode to systematically train, financially stimulate innovators, and evaluate the contribution of an individual employee to the company's success. Situational analysis is based on the study of a variety of project scenarios to select the optimal option and allows setting the order of distribution of the innovation across objects; determine the most profitable technology, based on a given set of possible events; and solve other problems (Remer and 1995). The study is carried out with relatively simple methods in a volume that increases the validity of decisions made. Complications of analysis are useless due to the objective uncertainty of events. The benefits obtained must exceed the research costs. In a broad sense, situational analysis involves studying the factors of the effect of innovation in various areas under changing conditions. It allows identifying the best opportunities for realizing innovation's potential, considering typical and atypical conditions for project evaluation (Crepon et al.,1998). Situational analysis of innovative projects involves their comparison with each other and with the technology used in practice. First, the differences that cause economic change are identified. Factors represent specific technical, organizational, and other differences in options (Brem and Radziwon, 2017). The analysis of causal relationships makes it possible to establish the influence of factors on the sources of effect, the corresponding intermediate and final economic indicators (Forsman, 2011). The factors are ranked in terms of importance in general and for a given set of circumstances. The likelihood of different situations could be predicted to improve the analysis's accuracy (Fosfuri and Tribo, 2008).

In the situational analysis, it is important to assess the innovative potential at the company level and the macro-level (Forsman, 2011). Thus, the differentiation of energy tariffs makes the calculating commercial efficiency of energy-saving projects incomparable in various companies. Projects with large heat savings in physical terms may appear less profitable due to low tariffs. Comparability of measures is ensured by uniform estimates of the cost of heat energy from national interests. Similarly, when assessing mini-stations' efficiency using local fuel, it is necessary to consider the high cost of the energy received and the reduction in the load in centralized heating networks. Disconnecting companies from the networks can lead to positive and negative results, based on the region's demand for heat.

The realized efficiency is expressed by the absolute effect and benefit of replacing the existing variant. It shows the project's impact on building innovative potential and on the company's activities in general. For example, the profit could be determined by introducing new equipment or the increase in profit from replacing existing equipment (Loof and Heshmati, 2006). Economic efficiency shows only one project's advantage over another, particularly the difference in the expected profit. In the first case, determining the feasibility of the project is solved, and in the second - the choice of the best project (Griliches, 1979). The 
cost-effectiveness could represent both realized and comparative benefits of the project. Such calculations reflect the well-known pattern of a decrease in the increase in each subsequent portion of costs (for example, energy production in the worst conditions, an increase in the technical characteristics of an object). It is assumed that similar technologies are applied in cases compared (Brem and Radziwon, 2017). Technically the same measures can affect a company's performance in different ways, depending on its plans and specific conditions. In practice, the realization of the economic benefits of innovations allows for many scenarios. Thus, energy-saving measures allow reducing the cost and price of products, increasing their competitiveness. The company's volume can be increased or remain at the same level (Cappa et al., 2016). A typical scenario for implementing the efficiency of using heat exchangers that are not associated with the main equipment and other similar measures is abstracted from the possible impact on production volume. Energy-saving due to such measures does not depend on product output. At the same time, the amount of energy savings can be influenced by the chosen technology option. Greater savings are achieved by using more expensive equipment. According to the typical scenario, the assessment of measures is carried out based on energy resources' economy. In turn, it is expressed by an increase in profit due to the saving of heat energy (Situation 1). If energy-saving leads to an increase in production (Situation 2), then the efficiency is determined based on revenue growth. The root cause is the reduction in energy costs and production costs. Secondary factors of action are to reduce the price of products and increase production (Crepon et al., 1998). This study provides the possibilities of analyzing these and other situations using specific examples. Situation 1. Calculation of the absolute effect of the innovation project is presented in Table 1.

Table 1. Indicators of the innovative energy-saving project, mIn UAH

\begin{tabular}{|c|c|c|c|c|c|c|c|}
\hline Indicator & Years & $B S P$ & 1 & 2 & 3 & 4 & 5 \\
\hline Investment & $(400)$ & 400 & & & & & \\
\hline Energy saving & & & 240 & 240 & 240 & 240 & 240 \\
\hline Costs (cost) & & & 123,6 & 123,6 & 123,6 & 123,6 & 123,6 \\
\hline Fuel and energy & & & 20 & 20 & 20 & 20 & 20 \\
\hline Other material costs & & & 10 & 10 & 10 & 10 & 10 \\
\hline Salary with accruals & & & 5,6 & 5,6 & 5,6 & 5,6 & 5,6 \\
\hline Amortization & & & 80 & 80 & 80 & 80 & 80 \\
\hline Repair, maintenance & & & 8 & 8 & 8 & 8 & 8 \\
\hline Balance sheet profit & & & 116,4 & 116,4 & 116,4 & 116,4 & 116,4 \\
\hline Profitability, $\%$ & & & 94,17 & 94,17 & 94,17 & 94,17 & 94,17 \\
\hline Income tax - $18 \%$ & & & $-20,95$ & $-20,95$ & $-20,95$ & $-20,95$ & $-20,95$ \\
\hline Profit & & & 95,45 & 95,45 & 95,45 & 95,45 & 95,45 \\
\hline Income & & & 175,45 & 175,45 & 175,45 & 175,45 & 175,45 \\
\hline Accumulated income (liquidity) & & & 175,45 & 350,9 & 526,35 & 701,8 & 877,25 \\
\hline Cash flow & & -400 & 175,45 & 175,45 & 175,45 & 175,45 & 175,45 \\
\hline Accumulated cash flow (acf) & & -400 & $-224,55$ & $-49,1$ & 126,35 & 301,8 & 477,25 \\
\hline Net present value (npv) $(11 \%)$ & & -400 & $-241,84$ & $-99,44$ & 28,86 & 144,43 & 248,55 \\
\hline
\end{tabular}

Sources: developed by the author.

As could be seen from Table 1, the net present value is:

NPV 1 year $=-400-(175,45 / 1,11) \times 1=-400-(+158,06)=-241,84 \mathrm{mln} \mathrm{UAH}$.

NPV 2 year $=-241,84-(175,45 / 1,11) \times 2=-241,84-(+142,399)=-99,44 \mathrm{mln} \mathrm{UAH}$.

NPV 3 year $=-99,44-(175,45 / 1,11) \times 3=-99,44-(+128,3)=28,86 \mathrm{mln}$ UAH.

NPV 4 year $=28,86-(175,45 / 1,11) \times 4=28,86-(+115,57)=144,43 \mathrm{mln}$ UAH.

NPV 5 year $=144,43-(175,45 / 1,11) \times 5=144,43-(+104,12)=248,55 \mathrm{mln}$ UAH. 
The use of equipment for energy saving worth $400 \mathrm{mln} \mathrm{UAH}$, excluding value-added tax, provides an annual energy saving of $240 \mathrm{mln} \mathrm{UAH}$. The equipment is put into operation immediately. This equipment's annual operating costs amount to $123.6 \mathrm{mln}$ UAH (including fuel and energy costs $-20 \mathrm{mln} \mathrm{UAH}$, equipment operation life - 5 years). It is assumed that the energy-saving measure does not affect the output and price of products. Possible changes to these parameters are not related to the event. Thus, they could be ignored. Situation 1 reflects a typical scenario for the implementation of the efficiency of energy-saving measures. The project is assessed in its pure form. Analysis and evaluation show the ability of the event to generate income, ensures the comparability of projects. The source of the measure's effectiveness is the reduction in production costs as a result of energy-saving, which is 116.4 (240-123.6) mIn UAH per year. Explanations for Table 1. Column «1» records the end of the 1 st year and the beginning of the 2 nd year, etc. Project indicators are expressed in comparable prices at the beginning of the billing period. The company's annual balance sheet profit resulted from the use of equipment for energy saving increases by $116.4 \mathrm{mln} \mathrm{UAH}$, and profit - by $95.45 \mathrm{mln} \mathrm{UAH}$. Income is equal to the sum of profit and depreciation deductions and amounts to $175.45(95.45+80)$ mln UAH. Cash flow represents the balance of income and capital investment from own resources. Accumulated cash flow (ACF) reflects the company's cash flow as a result of the project. The project's assessment in its pure form shows that over 5 years, the company's free funds in compared prices would increase by $477.25 \mathrm{mln}$ UAH. The net present value is the discounted accumulated cash flow that shows the event's effectiveness, taking into account the investor's return rate. Discounting is a methodological technique that allows comparing amounts of money that refer to different times. The typical rate of return (discount rate) is $11 \%$. Investments are advisable if the effect is positive. The net present value for 5 years is $248.46 \mathrm{mln} \mathrm{UAH}$. That means that considering the return rate (11\%), the investor would first return the invested capital (400 mln UAH). That means that considering the return rate $(11 \%)$, the investor, at first, would return the invested capital (400 mln UAH). Secondly, he would receive a standard annual income (11\%) and, thirdly, in 5 years, he will additionally receive the amount equivalent to $248.46 \mathrm{mln} \mathrm{UAH}$ at the beginning of the billing period. The payback period is 2.28 years $(400 / 175.45)$. Reducing the cost of products, including through energy conservation, can be an important condition for increasing the company's innovative potential, increasing competitiveness, maintaining and increasing the sales market. Suppose that the company's capacity allows for increasing the production and sales of products. The corresponding situation is discussed below. Tables 2 and 3 present the initial data on the innovative project for 5 years. Situation 2 . Increase in production output because of energy-saving equipment.

Table 2. Initial data on an innovative project with an increase in production because of the introduction of energy-saving measures, mln UAH

\begin{tabular}{lccc}
\hline \multicolumn{1}{c}{ Annual indicators } & The basic option & A new option & Difference (+/-) \\
\hline Investment & & 400 & +188 \\
Receipts & 2351,6 & 2539,6 & $+37,92$ \\
Value added tax (vat) - 20\% & 470,0 & 507,92 & $+3,79$ \\
Payments (taxes) from revenue - 2\% & 47,0 & 50,79 & $+82,6$ \\
Costs (cost) & 1709,0 & 1791,6 & +140 \\
Raw materials & 700 & 840 & +12 \\
Materials for production & 40 & 52 & -180 \\
Fuel and energy & 560 & 380 & +2 \\
Other material costs & 50 & 52 & $+16,6$ \\
Salary with accruals & 139 & 155,6 & +80 \\
Amortization & 200 & 280 & +12 \\
Repair, maintenance & 20 & 32 & $+124,31$ \\
Expenses, payments, vat & 2226,0 & 2350,31 & \\
\hline
\end{tabular}


Sources: developed by the author.

The company's profit is assessed when the volume of production increases. The basic variant indicators are determined without the use of energy-saving equipment, while the new one - provided that this equipment is used. Situation 2 reflects a specific innovative project based on the company's forecast with an increase in revenue. The forecast indicators of the company «without a project» (basic version) and «with a project» (new version) are compared to calculate the efficiency of energy-saving, considering the increase in the volume of production.

Table 3. Indicators for an innovative project with an increase in production because of the implementation of energy-saving measures, mIn UAH

\begin{tabular}{|c|c|c|c|c|c|c|}
\hline Indicator & 0 & 1 & 2 & 3 & 4 & 5 \\
\hline Investment & 400 & & & & & \\
\hline Revenue difference & & 188 & 188 & 188 & 188 & 188 \\
\hline Vat $-20 \%$ & & 37,92 & 37,92 & 37,92 & 37,92 & 37,92 \\
\hline Payments (taxes) from revenue $-2 \%$ & & 3,79 & 3,79 & 3,79 & 3,79 & 3,79 \\
\hline Cost difference (cost) & & 82,6 & 82,6 & 82,6 & 82,6 & 82,6 \\
\hline Raw materials & & 140 & 140 & 140 & 140 & 140 \\
\hline Materials for production & & 12 & 12 & 12 & 12 & 12 \\
\hline Fuel and energy & & -180 & -180 & -180 & -180 & -180 \\
\hline Other material costs & & 2 & 2 & 2 & 2 & 2 \\
\hline Salary with accruals & & 16,6 & 16,6 & 16,6 & 16,6 & 16,6 \\
\hline Amortization & & 80 & 80 & 80 & 80 & 80 \\
\hline Repair, maintenance & & 12 & 12 & 12 & 12 & 12 \\
\hline The difference between costs and taxes & & 124,31 & 124,31 & 124,31 & 124,31 & 124,31 \\
\hline Increase in balance sheet profit & & 63,69 & 63,69 & 63,69 & 63,69 & 63,69 \\
\hline Income tax - $18 \%$ & & $-11,46$ & $-11,46$ & $-11,46$ & $-11,46$ & $-11,46$ \\
\hline Increase profits & & 52,23 & 52,23 & 52,23 & 52,23 & 52,23 \\
\hline Income & & 132,23 & 132,23 & 132,23 & 132,23 & 132,23 \\
\hline Accumulated income (liquidity) & & 132,23 & 264,46 & 396,69 & 528,92 & 661,15 \\
\hline Cash flow & -400 & 132,23 & 132,23 & 132,23 & 132,23 & 132,23 \\
\hline Accumulated cash flow (acf) & -400 & $-267,77$ & $-135,54$ & $-3,31$ & 128,92 & 261,15 \\
\hline Net present value $(11 \%)$ & -400 & $-280,87$ & $-173,55$ & $-76,86$ & 10,24 & 88,72 \\
\hline
\end{tabular}

Sources: developed by the author.

Table 2 presents the output data «Express analysis» for situation 2. In turn, Table 3 shows the difference in indicators for the new and basic options. Besides, it stands to mention that the sign «-» shows the company's fuel and energy savings. The project is financed from its funds of $400 \mathrm{mln} \mathrm{UAH}$. The effectiveness of the application is calculated based on the difference in the indicators of the options. Net present value is $88.72 \mathrm{mln} \mathrm{UAH}$.

$$
\begin{aligned}
& \text { NPV } 1 \text { year }=-400-(132,23 / 1,11) \times 1=-400-(+119,13)=-280,87 \mathrm{mln} \cup A H . \\
& \text { NPV } 2 \text { year }=-280,87-(132,23 / 1,11) \times 2=-280,87-(+107,32)=-173,55 \mathrm{mln} \mathrm{UAH} . \\
& \text { NPV } 3 \text { year }=-173,55-(132,23 / 1,11) \times 3=-173,55-(+96,69)=-76,86 \mathrm{mln} \mathrm{UAH} . \\
& \text { NPV } 4 \text { year }=-76,86-(132,23 / 1,11) \times 4=-76,86-(+87,11)=10,24 \mathrm{mln} \text { UAH. } \\
& \text { NPV } 5 \text { year }=10,24-(132,23 / 1,11) \times 5=10,24-(+78,475)=88,72 \mathrm{mln} \text { UAH. }
\end{aligned}
$$

The study found that Situation 2 differs significantly from Situation 1 , since not one. Still, two efficiency factors are at work (using energy-saving equipment and an increase in production due to a decrease in product prices). In situation 1, the event does not affect the output and price of products. In turn, the source of efficiency is lower production costs. Table 1 demonstrates the increase in annual income is $95.45 \mathrm{mln}$ $\mathrm{UAH}$, income $-175.45 \mathrm{mln} \mathrm{UAH}$. A typical scenario assumes the stability of these indicators. However, in 
practice, many other scenarios are possible. Thus, the invariability of the price of products can lead to the loss of its competitiveness. Reducing the cost of products due to energy saving allows you to reduce their prices by $10 \%$, develop new sales markets, and increase revenue.

The source of efficiency is revenue growth. The product output markup in kind is $20 \%$. Table 2 shows that the annual revenue increases from $2351.6 \mathrm{mln} \mathrm{UAH}$ to $2539.6 \mathrm{mln} \mathrm{UAH}$. The annual income increase is $52.23 \mathrm{mln} \mathrm{UAH}$, and the income is $132.23 \mathrm{mln} \mathrm{UAH}$ (Table 3). It stands to mention that one of the important provisions of the situational analysis is the rational consideration of future events' probability. In many cases, complex analysis models are impractical, since the accuracy of estimates is limited, first of all, by the accuracy of the initial data. The study of typical scenarios (Situation 1) is reduced to selecting projects for acceptable and unacceptable risks within one given set of circumstances. For example, a range of energy-saving efficiency is determined with different increases in fuel cost. In situation 2, as a whole, several sets of circumstances need to be considered. The indicators of tables 2 and 3 can be predicted, for example, with a minimal increase in revenue in the new version. The effectiveness of the event would be minimal. Maximum efficiency would be obtained with the sales market's loss in the base case and the forecast of maximizing revenue growth in the new version. In the situational analysis, the calculation technology does not cause difficulties. Universal forms of documents and algorithms for evaluating innovative projects are prepared automatically. It is necessary to select the content and type of assessment of the innovative project correctly in the list presented in Table 4.

Table 4. List of types of project evaluations

\begin{tabular}{|c|c|}
\hline Types of project evaluations & Assignment of assessments and explanations \\
\hline $\begin{array}{l}\text { The absolute effect of an innovative } \\
\text { project }\end{array}$ & $\begin{array}{l}\text { Assessment of the feasibility of the project. Calculation of realized efficiency. } \\
\text { Evaluation of clean and concretized projects }\end{array}$ \\
\hline $\begin{array}{l}\text { Replacing the option with a less } \\
\text { expensive * or more profitable one }\end{array}$ & $\begin{array}{l}\text { Assessment of the feasibility of replacing the current option (technology, } \\
\text { method of management). Calculation of realized efficiency. The basic } \\
\text { version is competitive }\end{array}$ \\
\hline $\begin{array}{l}\text { Comparison of options by cost * or } \\
\text { by income }\end{array}$ & $\begin{array}{l}\text { Assess the benefits of one project over another. The calculation of } \\
\text { comparative efficiency provides the choice of the best project but does not } \\
\text { show its feasibility }\end{array}$ \\
\hline $\begin{array}{l}\text { Calculation of the feasibility of } \\
\text { additional costs }\end{array}$ & $\begin{array}{l}\text { Calculation of the feasibility of costs for improving technology to increase } \\
\text { the result (products, services, energy savings). Calculations of the realized } \\
\text { and comparative effect }\end{array}$ \\
\hline
\end{tabular}

Source: developed by the author on the basis of (Dachs et al., 2008).

In Situation 1, it is energy-saving and the innovative project's absolute efficiency, and in situation 2 production and replacement of the option with a more profitable one. Note that in situations 1 and 2, the new technique does not replace the existing one. An example of such a replacement is given below.

Situation 3. Replacement of the existing energy-saving technique. The assessment could be carried out under equality or inequality of energy savings and the constant or increase in the company's revenue. For brevity of the material's presentation, there is presented only a calculation with an annual energy savings of $240 \mathrm{mln} \mathrm{UAH}$. The operating technique is amortized. The type of assessment of an innovative project is replacing an option with a less expensive one. Tables 5 and 6 demonstrates the initial data and calculation of the effectiveness of the measure.

NPV 1 year $=-400-(159,05 / 1,11) \times 1=400-(+143,29)=-256,7 \mathrm{mln} \mathrm{UAH}$.

NPV 2 year $=-256,7-(159,05 / 1,11) \times 2=-256,7-(+129,1)=-127,6 \mathrm{mln} \mathrm{UAH}$.

NPV 3 year $=-127,6-(159,05 / 1,11) \times 3=-127,6-(+116,299)=-11,3 \mathrm{mln}$ UAH.

NPV 4 year $=-11,3-(159,05 / 1,11) \times 4=-11,3-(+104,77)=93,47 \mathrm{mln} \mathrm{UAH}$. 
NPV 5 year $=93,47-(159,05 / 1,11) \times 5=93,47-(+94,39)=187,86 \mathrm{mln}$ UAH.

Table 5. Indicators of existing equipment (basic version) and new equipment for an innovative project (new version), mIn UAH

\begin{tabular}{|c|c|c|}
\hline Annual indicators & The basic option & A new option \\
\hline Investment & - & 400 \\
\hline Costs (cost), including: & 220,0 & 123,6 \\
\hline Amortization & - & 80 \\
\hline
\end{tabular}

Sources: developed by the author.

Table 6. Calculation of the efficiency of replacing existing equipment (basic version) with new equipment for an innovative project (new version), mIn UAH

\begin{tabular}{|c|c|c|c|c|c|c|}
\hline Indicator & 0 & 1 & 2 & 3 & 4 & 5 \\
\hline Investment & 400 & & & & & \\
\hline $\begin{array}{l}\text { Costs (basic option) } \\
\text { including depreciation }\end{array}$ & & 220,0 & 220,0 & 220,0 & 220,0 & 220,0 \\
\hline Costs (new version) & & 123,6 & 123,6 & 123,6 & 123,6 & 123,6 \\
\hline including depreciation & & 80 & 80 & 80 & 80 & 80 \\
\hline Increase in balance sheet profit & & 96,4 & 96,4 & 96,4 & 96,4 & 96,4 \\
\hline Income tax $-18 \%$ & & 17,35 & 17,35 & 17,35 & 17,35 & 17,35 \\
\hline Increase profits & & 79,05 & 79,05 & 79,05 & 79,05 & 79,05 \\
\hline Income & & 159,05 & 159,05 & 159,05 & 159,05 & 159,05 \\
\hline Accumulated income (liquidity) & & 159,05 & 318,1 & 477,15 & 636,2 & 795,25 \\
\hline Cash flow & -400 & 159,05 & 159,05 & 159,05 & 159,05 & 159,05 \\
\hline Accumulated cash flow (ACF) & -400 & $-240,95$ & $-81,9$ & 77,15 & 236,2 & 395,25 \\
\hline Net present value (NPV) (11\%) & -400 & $-256,71$ & $-127,6$ & $-11,3$ & 93,47 & 187,86 \\
\hline
\end{tabular}

Sources: developed by the author.

Comparative options are identical in the result (energy-savings). Only the necessary costs are compared to simplify the selection of the best option. No capital investment is needed in the basic version, and there are no depreciation charges since the equipment is depreciated. The replacement of equipment increases the company's annual balance sheet profit by $96.4 \mathrm{mIn} \mathrm{UAH}$, and revenue - by $159.05 \mathrm{mln} \mathrm{UAH}$. In case of refusal from the innovative project, the use of existing equipment would continue, providing an increase in the annual balance sheet profit by saving energy resources by 20 (240-220) mln UAH. The accumulated cash flow because of equipment replacement over 5 years is $395.25 \mathrm{mln}$ UAH. This means that investments in new equipment increase the company's free funds by $395.25 \mathrm{mln}$ UAH. Net present value is $187.86 \mathrm{mln} \mathrm{UAH}$. The maximum capital investment is approximately $587.86(400+187.86)$ $\mathrm{mln} \mathrm{UAH}$. Therefore, the purchase of new equipment is advisable for an amount not exceeding $587.86 \mathrm{mln}$ UAH.

Situation 4. The choice of the best model of equipment for energy saving is based on the comparative effect calculation. In case the models (options) of equipment are identical in terms of the result, i.e. they provide the same fuel and energy savings, the amortization period is 5 years. The best solution to a problem is determined by comparing costs. The equipment in model 2 is more expensive, but model 1 is cheaper to operate. Project evaluation type - comparison of cost options. Table 7 provides the initial data, while Table 8 - the calculation of the comparative effect. This assessment shows a more profitable solution. Its peculiarity is that the chosen best option may turn out to be economically inexpedient. Therefore, in the general case, a combination of comparative and realized efficiency calculations is required (situations 1-3). 
Table 7. Indicators of equipment of model 1 (basic variant) and model 2 on the innovative project (new variant), mIn UAH

\begin{tabular}{lcc}
\hline \multicolumn{1}{c}{ Annual indicators } & The basic option & A new option \\
\hline Investment & 390 & 400 \\
Costs (cost), including: & 130,0 & 123,6 \\
Amortization & 76 & 80 \\
\hline
\end{tabular}

Source: developed by the author.

Table 8. Calculation of comparative efficiency to determine a more economical option (model) of energy-saving equipment for an innovative project, $\operatorname{mln} \mathrm{UAH}$

\begin{tabular}{|c|c|c|c|c|c|c|}
\hline Indicator & 0 & 1 & 2 & 3 & 4 & 5 \\
\hline Increase investment & 10 & & & & & \\
\hline Costs (option 1) & & 130,0 & 130,0 & 130,0 & 130,0 & 130,0 \\
\hline Including depreciation & & 76 & 76 & 76 & 76 & 76 \\
\hline Costs (option 2) & & 123,6 & 123,6 & 123,6 & 123,6 & 123,6 \\
\hline including depreciation & & 80 & 80 & 80 & 80 & 80 \\
\hline Increase in balance sheet profit & & 6,4 & 6,4 & 6,4 & 6,4 & 6,4 \\
\hline Income tax - $18 \%$ & & 1,15 & 1,15 & 1,15 & 1,15 & 1,15 \\
\hline Increase profits & & 5,25 & 5,25 & 5,25 & 5,25 & 5,25 \\
\hline Income & & 9,25 & 9,25 & 9,25 & 9,25 & 9,25 \\
\hline Accumulated income (liquidity) & & 9,25 & 18,5 & 27,75 & 37 & 46,25 \\
\hline Cash flow & -10 & 9,25 & 9,25 & 9,25 & 9,25 & 9,25 \\
\hline Accumulated cash flow (ACF) & -10 & $-0,75$ & 8,5 & 17,75 & 27,0 & 36,25 \\
\hline Net present value $(11 \%)$ & -10 & $-1,85$ & 5,5 & 12,12 & 18,08 & 23,45 \\
\hline
\end{tabular}

Sources: developed by the author.

$$
\begin{aligned}
& \text { NPV } 1 \text { year }=-10-(9,05 / 1,11) \times 1=-10-(+8,153)=-1,85 \mathrm{mln} \text { UAH. } \\
& \text { NPV } 2 \text { year }=-1,85-(9,05 / 1,11) \times 2=-1,85-(+7,35)=5,5 \mathrm{mln} \text { UAH. } \\
& \text { NPV } 3 \text { year }=5,5-(9,05 / 1,11) \times 3=5,5-(+6,62)=12,12 \mathrm{mln} \text { UAH. } \\
& \text { NPV } 4 \text { year }=12,12-(9,05 / 1,11) \times 4=12,12-(+5,96)=18,08 \mathrm{mln} \text { UAH. } \\
& \text { NPV } 5 \text { year }=18,08-(9,05 / 1,11) \times 5=18,08-(+5,37)=23,45 \mathrm{mln} \text { UAH. }
\end{aligned}
$$

Increases in profit, income, and other comparative efficiency indicators can be recorded in the company's statements only if comparative equipment models are actually introduced. A decrease in operating costs should offset the increase in the cost of equipment by $10 \mathrm{mln} \mathrm{UAH}$. As a result of the cost reduction, the company's annual balance sheet profit is $6.4 \mathrm{mln} \mathrm{UAH}$, and the profit is $5.25 \mathrm{mln} \mathrm{UAH}$. Annual income is $9.25 \mathrm{mln} \mathrm{UAH}$. Income is equal to the increase in profit plus depreciation for option 2 minus depreciation for option 1. The accumulated cash flow of the equipment service life is $36.25 \mathrm{mln} \mathrm{UAH}$. This means that model 2 equipment instead of model 1 provides an increase in the company's free funds by $36.25 \mathrm{mln}$ UAH. Net present value is $23.45 \mathrm{mln}$ UAH. Thus, the positive value of net present value shows that the discounted cash inflows exceed the discounted amount of capital investments during the settlement period. Therefore, it provides an increase in innovation potential and increases the value of the companyNote that the assessment of innovative projects cannot be carried out in isolation from the company as an operating system with its characteristics, depending on the industry, organizational structure, type of production organization. These requirements can be summarized as follows:

1. An innovative project has to be assessed at all stages of the life cycle of an innovative product. Therefore, the corresponding prices, costs and production scales have to be determined at each stage. 
2. An innovative project can be considered in isolation only as an exception. In general, an integrated approach is required, considering that a company can implement several innovative projects at different stages of the life cycle and produce ordinary products. Therefore, innovation should be assessed in conjunction with other company activities.

3. For each stage of the project's life cycle, it is necessary to decide which market structure it belongs to. It is possible that at the first stage of the life cycle, it will be a monopoly. Therefore, it leads to the need to determine prices and production scales.

4. When considering innovative projects, it is advisable to consider the nature of innovation, the industry's competitive position and the innovating company itself, the determinants, demand (product quality, advertising, distribution channels, etc.).

It follows from these requirements that the main thing is the price of a new product at each stage. The discounting method assumes that prices are already known in advance, and all assessments of the effectiveness of an innovative project are carried out only in the sphere of production. Meanwhile, the effectiveness of an innovative project should be determined by its consumption sphere, which should be reflected in the selling price. The price reflects the «value» of the new product for the consumer, for whom it is being created.

Only large companies could allocate about $\$ 1 \mathrm{mln}$ a year for these purposes without prejudice to their core business. However, nowadays, in Ukraine, not many such companies could afford to engage in technological innovations. The scale factor in innovation operates fundamentally. The larger the company, the more likely it is to be innovatively active. In turn, the state could stimulate the growth of other companies' innovative potential if, through state orders, it guarantees the primary demand for innovative products. Entrepreneurs are reluctant to invest in modernization and innovation. The situation continues to deteriorate worries the country's leadership, if only because the economy's raw material orientation makes it especially unstable during periods of cyclical crises and market fluctuations. However, there is no definite answer to how to accelerate the economy's diversification and increase the share of scienceintensive products in Ukraine's GDP. From a business perspective, innovation is necessary and desirable if it is a tool for increasing added value and competitiveness. In another case, business is not very interested in them. That is why the potential lies in innovations being successfully implemented in the USA, Japan, China, but not in Ukraine, where «the instrument of additional value is positioned in a slightly different area». To introduce innovations, it is necessary to ensure a stable demand for them, which «must be provided with motor skills, so that this innovation is not just declared, but implemented». The success or unsuccessful promotion of an innovative product to the market is determined not only by the availability of demand. To get things off the ground, three components (money, demand, and ability) are needed to establish a pilot production quickly. A developed innovation system provides for the stimulation of relationships between all participants in innovation processes.

Conclusions. The proposed method for determining the effectiveness of introducing innovations to build up a company's innovative potential based on a situational analysis of the dynamic indicators of innovative changes could be applied both in stable and transitional periods of the company's activity. The criterion for the economic efficiency of energy saving in the company is the degree of increase in production profitability after implementing the planned measures. For example, it is possible to determine the profit from introducing new equipment or the increase in profit from replacing existing equipment. Efficiency shows only the advantage of one project over another, particularly the difference in the expected profit. In the first case, determining the feasibility of the project is solved, and in the second - the choice of the best project. The main indicator of the efficiency of a resource-saving measure is the minimum payback period for its implementation. Technically the same measures could affect a company's performance in different ways, depending on its plans and specific conditions. In practice, the realization of the economic benefits of innovations allows for many scenarios. Energy-saving measures help to 
reduce the cost and price of products to increase their competitiveness. The volume of production in the company could be increased or remain at the same level. In the calculations, one should hypothesize that all investments directed to energy-saving measures are borrowed. In this case, it is natural to consider the interests of the investor or credit institution. A payback has to secure the return of the loan or the investor's dividend. Herewith, the event has to be effective that it allows the subject to implement it paying off the loan as soon as possible and without losing its benefits. Thus, the funds used for resource conservation can be capitalized or directed to replenish their own working capital. In such conditions, it is necessary to determine the economic feasibility of implementing any considered energy-saving measure:

1. For rational compliance with the technological process;

2. By the payback period (amortization period);

3. By the state of fixed assets (moral and physical wear and tear);

4. The rate of inflationary changes (growth in the price of resources);

5. Limited natural and financial resources;

6. According to the method of application (reconstruction);

7. By the method of implementation (with or without stopping production);

8. By funding sources (capital investments, own circulating assets, non-capital expenditures).

The calculations aimed to identify a set of energy-saving measures that would allow the company to ensure the maximum total effect and affect the management's decision to allocate funds for its implementation. However, such a proposal is permissible only in cases where the one-time costs of carrying out work to optimize equipment for energy saving would be used more efficiently than when implementing the tasks for which they were previously assigned.

The assessment of measures is carried out based on the economy of energy resources and is expressed by an increase in profit due to saving heat energy (Situation 1). If the energy-saving measure increases production (Situation 2), efficiency is determined based on revenue growth. The first reason is the reduction in energy costs and production costs. Secondary factors of action are to reduce the price of products and increase production. Situation 2 differs significantly from Situation 1, since not one, but two factors of efficiency are at work (the use of energy-saving equipment and an increase in production due to a decrease in product prices). Besides, in Situation 1, the event does not affect the output and price of products. The source of efficiency is lower production costs. The increase in annual income is $95.45 \mathrm{mln}$ UAH, income - $175.45 \mathrm{mln} \mathrm{UAH}$. The study's applied significance lies in the fact as follow. The improved methodological toolkit for assessing the companies' innovative potential and the mechanism for the scientific and technical developments commercialization based on a situational analysis can solve management problems. These problems result from the lack of own competencies and difficulties that cause distraction from the company's management resources to develop innovative activities and the formation of corporate standards governing investment activities and building innovative potential.

\section{References}

Amara, N., \& Landry, R. (2005). Sources of information as determinants of novelty of innovation in manufacturing firms: evidence from the 1999 statistics Canada innovation survey. Technovation, 25(3), 245-259. [Google Scholar] [CrossRef]

Antikainen, M., Mäkipää, M., \& Ahonen, M. (2010). Motivating and supporting collaboration in open innovation. European Journal of Innovation Management, (13)1, 100-119. [Google Scholar] [CrossRef]

Archibugi, D. (1996). National innovation systems. a comparative analysis. Research Policy, 5(25), 838-842.

Basant, R., \& Fikkert, B. (1996). The effects of R\&D, foreign technology purchase, and domestic and international spillovers on productivity in Indian firms. The Review of Economics and Statistics, 187-199. [Google Scholar] [CrossRef]

Belderbos, R., Carree, M., \& Lokshin, B. (2004). Cooperative R\&D and firm performance. Research policy, 33(10), 1477-1492. [Google Scholar] [CrossRef

Boons, F., Montalvo, C., Quist, J., \& Wagner, M. (2013). Sustainable innovation, business models and economic performance: an overview. Journal of Cleaner Production, 45, 1-8. [Google Scholar] [CrossRef] 
Brem, A., \& Radziwon, A. (2017). Efficient Triple Helix collaboration fostering local niche innovation projects-A case from Denmark. Technological Forecasting and Social Change, 123, 130-141. [Google Scholar] [CrossRef]

Brem, A., Maier, M., \& Wimschneider, C. (2016). Competitive advantage through innovation: the case of Nespresso. European Journal of Innovation Management, 19(1), 133-148. [Google Scholar] [CrossRef]

Cappa, F., Del Sette, F., Hayes, D., \& Rosso, F. (2016). How to deliver open sustainable innovation: An integrated approach for a sustainable marketable product. Sustainability, 8(12), 1341. [Google Scholar] [CrossRef]

Cassiman, B., \& Veugelers, R. (2006). In search of complementarity in innovation strategy: Internal R\&D and external knowledge acquisition. Management science, 52(1), 68-82. [Google Scholar] [CrossRef]

Cho, C., \& Lee, S. (2015). How firms can get ideas from users for sustainable business innovation. Sustainability, 7(12), 1603916059. [Google Scholar] [CrossRef]

Crépon, B., Duguet, E., \& Mairessec, J. (1998). Research, Innovation And Productivi [Ty: An Econometric Analysis At The Firm Level. Economics of Innovation and new Technology, 7(2), 115-158. [Google Scholar] [CrossRef]

Dachs, B., Ebersberger, B., \& Loof, H. (2008). The innovative performance of foreign-owned enterprises in small open economies. The Journal of Technology Transfer, 33(4), 393-406. [Google Scholar] [CrossRef]

Dewar, R. D., \& Dutton, J. E. (1986). The adoption of radical and incremental innovations: An empirical analysis. Management science, 32(11), 1422-1433. [Google Scholar] [CrossRef]

Evangelista, R., Perani, G., Rapiti, F., \& Archibuqi, D. (1997). Nature and impact of innovation in manufacturing industry: some evidence from the Italian innovation survey. Research policy, 26(4-5), 521-536. [Google Scholar] [CrossRef]

Forsman, H. (2011). Innovation capacity and innovation development in small enterprises. A comparison between the manufacturing and service sectors. Research policy, 40(5), 739-750. [Google Scholar] [CrossRef]

Fosfuri, A., \& Tribo, J. A. (2008). Exploring the antecedents of potential absorptive capacity and its impact on innovation performance. Omega, 36(2), 173-187. [Google Scholar] [CrossRef]

Fountain, J. E. (1998). Social capital: Its relationship to innovation in science and technology. Science and Public Policy, 25(2), 103-115. [Google Scholar] [CrossRef]

Griliches, Z. (1979). Issues in assessing the contribution of research and development to productivity growth. The bell journal of economics, 92-116. [Google Scholar] [CrossRef]

Grimaldi, M., Cricelli, L., \& Rogo, F. (2012). A methodology to assess value creation in communities of innovation. Journal of Intellectual Capital, 13(3), 305-330. [Google Scholar] [CrossRef]

Helfat, C. E., \& Quinn, J. B. (2006). Open innovation: The new imperative for creating and profiting from technology. Academy of Management Perspectives, 20(2), 86-88. [Google Scholar] [CrossRef]

Jaffe, A. (1986). Technological Opportunity and Spillovers of R\&D: Evidence from Firms' Patents, Profits and Market Value. American Economic Review, 76, 984. [Google Scholar]

Jones, C. I. (1995). R \& D-based models of economic growth. Journal of political Economy, 103(4), 759-784. [Google Scholar] [CrossRef

Karim, S. (2009). Business unit reorganization and innovation in new product markets. Management Science, 55(7), $1237-1254$ [Google Scholar] [CrossRef]

Loof, H., \& Heshmati, A. (2006). On the relationship between innovation and performance: A sensitivity analysis. Economics of Innovation and New Technology, 15(4-5), 317-344. [Google Scholar] [CrossRef]

Maskell, P. (2000). Social capital, innovation, and competitiveness. In Social capital (pp. 111-123). Oxford University Press.

Milgrom, P., \& Roberts, J. (1995). Complementarities and fit strategy, structure, and organizational change in manufacturing. Journal of accounting and economics, 19(2-3), 179-208. [Google Scholar] [CrossRef]

Murovec, N., \& Prodan, I. (2009). Absorptive capacity, its determinants, and influence on innovation output: Cross-cultural validation of the structural model. Technovation, 29(12), 859-872. [Google Scholar] [CrossRef]

Newman, A., Gao, Y., \& Zheng, J. (2015). Overcoming the innovation challenge: examining the determinants of new product innovation in Chinese SMEs. In Developments in Chinese Entrepreneurship (pp. 33-57). Palgrave Macmillan, New York. [Google Scholar] [CrossRef

Pisano, G. P. (1990). The R\&D boundaries of the firm: an empirical analysis. Administrative science quarterly, 153-176. [Google Scholar] [CrossRef]

Prokop, V., Stejskal, J., \& Kuvíková, H. (2017). The Different Drivers of Innovation Activities in European Countries: A Comparative Study of Czech, Slovak, and Hungarian Manufacturing Firms 1. Ekonomicky Casopis, 65(1), 31. [Google Scholar]

Remer, D. S., \& Nieto, A. P. (1995). A compendium and comparison of 25 project evaluation techniques. Part 1: Net present value and rate of return methods. International journal of production economics, 42(1), 79-96. [Google Scholar] [CrossRef]

Varis, M., \& Littunen, H. (2010). Types of innovation, sources of information and performance in entrepreneurial SMEs. European Journal of Innovation Management, 13, 128-154. [Google Scholar] [CrossRef] 
Сі Цо Чан, компанія «Zhejiang Golden Egg technology LTD», Китай; Київський національний університет імені Тараса Шевченка, Україна

Впровадження інновацій в компанії: ситуаційний аналіз

у статmі висвітлено особливості впровадження інновацій на рівні компанії, як одного з найважливіших способів трансформації виробничого процесу. Систематизація наукового доробку за тематикою дослідження свідчить про те, що науковці приділяють недостатньо уваги дослідженню проблемних аспектів ситуаційного аналізу та методів оцінки ефективності впровадження інновацій вітчизняними компаніями. Таким чином, актуальність статті полягає в необхідності застосування економіко-математичного апарату для обгрунтування доцільності впровадження інновацій в компанії для підвищення її конкурентоспроможності. Метою статті є розробка рекомендацій щодо нарощення інноваційного потенціалу компанії на основі обгрунтування науково-практичних положень щодо комплексної оцінки ефрективності впровадження нововведень. Для досягнення поставленої мети, у ході дослідження здійснено ситуаційний аналіз динамічних показників інноваційних змін. У рамках дослідження проаналізовано методи оцінки впровадження інновацій та нововведень в компанії з точки зору інноваційного розвитку. Автором систематизовано наявні методи оцінки ефрективності інноваційної діяльності компанії. Розглянуто методи ситуаційного аналізу на прикладі енергозбереження. У статті представлено типові сценарії щодо оцінки ефрективності заходу з енергозбереження в компанії. У ході дослідження розраховано абсолютний ефект від впровадження інноваційного проєкту (визначено прибуток від введення в дію нового обладнання та при заміні наявної техніки). Крім того, розраховано ефрективність інноваційного проєкту при заміні наявної техніки (базовий варіант) на нове обладнання (новий варіант). Автором досліджено організаційно-економічне забезпечення для оцінки інноваційних заходів в компанії. Враховуючи отримані результати, розроблено методичні підходи до попереднього і підсумкового ситуаційного аналізу інноваційних проєктів та комплексного аналізу інноваційного потенціалу компанії. У роботі визначено об'єктивні передумови для зростання інноваційного потенціалу компанії. За результатами оцінки інноваційної діяльності компанії, запропоновано систему аналітичних показників щодо оцінки доцільності впровадження певного проєкту. Отримані результати дослідження мають прикладне значення та можуть бути застосованні з метою активізації інноваційної діяльності компаній та підвищення їх конкурентоспроможності на ринку.

Ключові слова: ефективність, заходи, інновації, інноваційний проєкт, методи оцінки, ситуаційний аналіз.

Manuscript received: 07.05.2020

(C) The author(s) 2020. This article is published with open access at Sumy State University 